\title{
ON TRANSLATING CRÉ NA CILLE
}

More talked about than read, for over threescore years Cré na Cille has been the buried treasure of modern Irish-language literature. Our aim in this translation is modest: to give the Anglophone reader the most accurate answer we can provide to the question, What is in this book? There is ample space in the shadow of Ó Cadhain for "versions," subjective interpretations, radical transpositions into other settings and periods, even parodies; these things will follow. But, be faithful to Ó Cadhain has been our first commandment. This of course involves much more than word-for-word equivalence. In English the words are often lacking, Ó Cadhain being a word addict with access to a world that feasted upon its verbal riches, having little else. So it has often been necessary to jump out of the footsteps of the Irish text, run round it, and fall in with it again at the next corner.

A word on our working method. My Irish was picked up in Aran and south Conamara in the middle of a busy life, when I was exploring and mapping those intricate landscapes; it was serviceable enough then for discussing states of the tide, the gossip of the townlands, and the promise of the potato crop, but nowadays it is hardly fit for public use. Hence the basis of our translation was produced by Liam, and then the two of us worked through it repeatedly, almost phrase by phrase. In searching for the English words that would most clearly convey Ó Cadhain's meaning, we have tried to avoid flattening out his extravagances, his anarchic wit, his otherness, his sheer strangeness. At an early stage parts of our text were circulated among anonymous readers by the publisher, eliciting a wide range of com- 
ments and suggestions, for all of which we are grateful, and some of which we have adopted, while feeling that their mutual contradictoriness left us free to follow our own lights, which implies that the shortcomings of the present version are entirely our own. Nevertheless we gratefully acknowledge the guidance of Éamon Ó Ciosáin and Gearóid Ó Crualaoich in negotiating some particularly tangled corners of Ó Cadhain's thorny masterpiece, and of Pádraig Ó Snodaigh, who read through and helpfully commented on our translation.

One of the most frequent and urgent recommendations made to us concerned what is almost an established practice with weighty precedents, of leaving personal names and placenames untranslated, in order to root the text in its original setting in time and space. There is point to this; one doesn't want to be pretending that Caitríona and her neighbours are buried in some present-day English graveyard. But there are other ways of preserving a whiff of the book's setting, its irreducible foreignness, across the linguistic gulf. The countless mentions in Cré na Cille of little stony fields, seaweed harvesting, holy wells, and so on, and the occasional references to a motor car, a movie, a woman in trousers, sufficiently locate it in a rural seaside community at a period when its folk ways are being invaded by modernity. (Also, if precedent is to be given weight in this debate, there is on the side of translation the splendid example of Brightcity, Eoghan Ó Tuairisc's version of Ó Cadhain's name for the city of Galway, in "An Bóthar go dtí an Ghealchathair.") The point is this. Placenames are semantically two-pronged. The placename on the one hand denotes a location, and on the other bears a load of connotations with it, including the associations that make a place, an element of a life-world, out of the bare location. But the places mentioned in Cré na Cille are fictional, which complicates the relationship between denotation and connotation; the only existence of these places is in the text, and all we know of them is what the text tells us, which it does partly through the placename itself. What is denoted is constituted by the connotations. Of Lake Wood, all we know is that there is or was a lake and a wood; but given the general setting we can imagine the place. Pasture Glen, the Common Field, Mangy Field, 
Flagstone Height, Donagh's Village, West Headland, Colm's Cove, Woody Hillside, the Deep Hollow, Roadside Field, the Hill Field, and so on, and so on - cumulatively these names paint a picture of a small-scale, well-worked countryside intimately known to its inhabitants. To replace them all with strings of letters the non-Irish-speaking reader will not even be able to pronounce would entail a tremendous loss of texture, of precious discriminations, of meaning. Of course there are difficult choices to be made in translating some of them. To avoid a touch of the English suburban estate we have rendered Lake Wood as Wood of the Lake, and Pasture Glen as Glen of the Pasture, for instance. Also, it's not possible to give the full sense of tamhnach in one or two English words - but such obstacles are just the usual ones that make translation a joy frustrated.

A similar argument applies to personal names, but in the present text it is not so pressing, since the English or anglicised equivalents of most of them - Cáit, Bríd, and the like-are obvious anyway. A few that are just English names spelled in the Irish phonetic system, such as Jeaic, we have let revert to their English forms. However, we found it necessary to translate nicknames, as they are indicative of status, appearance, ancestry, or the community's attitude towards the person named. So we have "Siúán the Shop" and "Máirtín Pockface," for example. As with placename elements there are some puzzles, of course: what exactly is implied by the nickname of Tomás Taobh Istigh we think we know, but the ambiguity of Jeaic na Scolóige's name is not just in our minds but commented on (unrevealingly) by other characters in the book.

Translation theorists speak of the "target language." I don't like the aggressive term; I'd rather think of a "host language" and what variety of it might most generously welcome this demanding but rewarding text. The formal principle-a bold invention- of Ó Cadhain's novel is that it is entirely composed of direct speech, with no explicit indication of who is speaking. So, for the reader to be able to ascribe each speech to the right speaker by its tone and vocabulary as well as its content, a dialect of English with a notable range of expressive means is called for, and of course in Ó Cadhain's 
own territory a Hiberno-English that has for centuries been living next door to and borrowing household items from the Irish language offers itself. The English of the Conamara Gaeltacht can range from bardic frenzy to cocksure modernism; but it is a potent brew, to be used with discretion; it is no use translating Irish into an English that itself calls for translation or has been debased by Paddywhackery.

Finally, and despite our sense of the enormity of what we have undertaken in opening to non-Irish readers' eyes a book so long aureoled in distant respect, I must say what a pleasure the task has been. I hope too that our partners Bairbre and M have found that their considerable contributions have been repaid in the wild humours of Ó Cadhain's Graveyard Clay.

Tim Robinson 